\title{
Clofazimine: A Promising Inhibitor of Rabies Virus
}

\author{
Jiajing $\mathrm{Wu}^{1,2 \dagger}$, Shouchun $\mathrm{Cao}^{3 \dagger}$, Shan $\mathrm{Lei}^{1 \dagger}$, Qiang $\mathrm{Liu}^{1 \dagger}$, Yinghong $\mathrm{Li}^{4}$, Yueyang $\mathrm{Yu}^{3}$, \\ Hui Xie ${ }^{1}$, Qianqian $\mathrm{Li}^{1}$, Xiaoqiang Zhao ${ }^{4}$, Ruifeng Chen ${ }^{1}$, Weijin Huang ${ }^{1}$, Xinyue Xiao ${ }^{5}$, \\ Yongxin $\mathrm{Yu}^{3}$, Danqing Song ${ }^{4 *}$, Yuhua $\mathrm{Li}^{3 *}$ and Youchun Wang ${ }^{1 *}$
}

${ }^{1}$ Department of HIVIAIDS and Sex-transmitted Virus Vaccines, National Institutes for Food and Drug Control, Beijing, China, ${ }^{2}$ Wuhan Institute of Biological Products, Hubei, China, ${ }^{3}$ Department of Arboviral Vaccine, National Institutes for Food and Drug Control, Beijing, China, ${ }^{4}$ Beijing Key Laboratory of Antimicrobial Agents, Institute of Medicinal Biotechnology, Chinese Academy of Medical Science and Peking Union Medical College, Beijing, China, ${ }^{5}$ Institute for Reference Standards and Standardization, National Institutes for Food and Drug Control, Beijing, China

OPEN ACCESS

Edited by: Heike Wulff,

University of California, Davis, United States

Reviewed by: Robert Lust,

The Brody School of Medicine at East Carolina University, United States George Chandy, University of California, Irvine, United States

*Correspondence: Youchun Wang wangyc@nifdc.org.cn Yuhua $L$

liyuhua@nifdc.org.cn

Danqing Song

songdanqingsdq@hotmail.com

${ }^{+}$These authors have contributed equally to this work

Specialty section: This article was submitted to Integrative and Regenerative Pharmacology, a section of the journal Frontiers in Pharmacology

Received: 24 August 2020 Accepted: 09 February 2021

Published: 18 March 2021

Citation:

Wu J, Cao S, Lei S, Liu Q, Li Y, Yu Y, Xie $H, L i Q$, Zhao $X$, Chen R, Huang $W$, Xiao $X, Y U Y$, Song $D, L i Y$ and Wang $Y$

(2021) Clofazimine: A Promising Inhibitor of Rabies Virus.

Front. Pharmacol. 12:598241. doi: 10.3389/fphar.2021.598241
With an almost $100 \%$ mortality rate, rabies virus (RABV) infection is a global concern. Limited post-exposure prophylaxis and lack of an effective treatment necessitate novel antiviral therapies against RABV. Here, using a high-throughput screening (HTS) method developed in our lab, 11 candidates with anti-RABV activity were identified from a library of 767 clinical drugs. Clofazimine (CFZ), an anti-leprosy drug, displayed an $\mathrm{EC}_{50}$ of $2.28 \mu \mathrm{M}$, and SI over 967 against RABV. Investigations into the underlying mechanisms revealed that CFZ targeted viral membrane fusion at the early stages of virus replication. Moreover, CFZ and Clofazimine salicylates (CFZS) exhibited elevated survival rates in vivo, compared with the positive control T-705. Thus, this study revealed CFZ as a promising drug against RABV infection.

Keywords: rabies virus, approved drugs, high-throughput screening, clofazimine, in vivo

\section{INTRODUCTION}

Rabies is a viral disease that causes inflammation of the brain in humans and other mammals (Dharmalingam and Jothi, 2015). Rabies virus (RABV), which causes rabies, is a negative-sense single stranded RNA virus of the genus Lyssavirus. Rabies can be prevented after a recognized exposure through appropriate wound care and application of post-exposure prophylaxis (PEP) as soon as possible. To prevent rabies virus from gaining access to the nervous system, the World Health Organization (WHO) recommends administering rabies immunoglobulin (RIG) along with four or five doses of rabies vaccine, especially in cases with severe exposure. However, approximately $40,000-70,000$ human die annually due to rabies worldwide, roughly $40 \%$ of which are children (Davis et al., 2015). The majority of these deaths occurred in Asia and Africa (Fooks et al., 2017). The main reasons are scarcity of RIG and failure to implement appropriate PEP (Jackson, 2013; World Health Organization, 2013).

So far, no effective treatment has been developed to cure the disease after the onset of symptoms (Fooks et al., 2014). Many small molecules have been identified as potential anti-RABV inhibitors but with little promise. Ribavirin, a guanine nucleoside analog, can effectively inhibit RABV replication

Abbreviations: NIFDC, National Institutes for Food and Drug Control; RABV, rabies virus; RFFIT, rapid fluorescent focus inhibition test; HTS, high-throughput screening; PEP, post-exposure prophylaxis; CFZ, Clofazimine; pRABV, pseudotyped rabies virus; pVSV: pseudotyped vesicular stomatitis virus; EC50, 50\% effective concentration; CC50, 50\% cytotoxic concentration; SI, Selectivity index. 
in vitro; however, it lacks clinical efficacy (Anindita et al., 2018). Favipiravir (6-fluoro-3-hydroxy-2-pyrazinecarboxamide), a pyrazine derivative, commonly known as T-705, is a broadspectrum RNA polymerase inhibitor that has an antiviral effect against $\mathrm{RABV}$ in vitro $\left(\mathrm{EC}_{50}=32.4 \mu \mathrm{M}\right.$, against a $\mathrm{RABV}$ vaccine strain) (Arias et al., 2014; Virojanapirom et al., 2016). In mouse models of rabies infection, T-705 (300 mg/kg/day) provided protection when administered $1 \mathrm{~h}$ after viral infection (Yamada et al., 2016), but no protection when treatment started 2 days after viral inoculation (Yamada et al., 2019). Higher doses (600 or $900 \mathrm{mg} / \mathrm{kg} /$ day) were reported to suppress viral replication in the CNS even when administration started 2 days after inoculation (Yamada et al., 2019). Other studies reported poor efficacy of T-705 in vivo, even when T-705 was combined with other anti-viral compounds (Banyard et al., 2019; Marosi et al., 2019). The deficient clinical efficacy suggested that it is not an ideal anti-RABV agent. In 2005, a 15-year-old girl in Wisconsin received a combination treatment with ketamine, ribavirin, amantadine, midazolam, and phenobarbital which later became popularly known as the "Milwaukee Protocol" (Willoughby Jr et al., 2005). Although this girl and four other patients survived after the treatment, at least six others infected with rabies died in the similar treatments. The subsequent failures caused a re-evaluation of the protocol, and it was revealed that ribavirin and amantadine failed to demonstrate efficacy in laboratory animals and recent evidence in primary neuron cultures and mice did not support the use of ketamine (Weli et al., 2006).

Thus, there is an urgent need to discover and develop new antiviral agents against RABV. Instead of developing new drugs, which usually takes many years for the development and has several manufacturing requirements, repurposing of existing drugs is an attractive alternative. The approved drugs are advantageous because their pharmacology and toxicity profiles are known, safety data in humans is established, and manufacturing and formulation feasibility has been demonstrated. In this study, we established a high-throughput screening (HTS) assay based on a pseudovirus containing a firefly luciferase reporter gene enveloped by the RABV glycoprotein $G$ (pRABV) to screen a library of 767 approved drugs for RABV entry inhibitors to identify an effective anti-RABV candidates.

\section{MATERIALS AND METHODS}

\section{Cell Lines, Plasmids, Pseudovirus, and Authentic Virus}

293T cells (CRL3216, ATCC, Manassas, VA), BSR (variant strain of BHK) cells, PG-4 cells (CRL2032, ATCC) were cultured in 5\% $\mathrm{CO} 2$ at $37^{\circ} \mathrm{C}$ in high glucose Dulbecco's Modified Eagle's Medium (HyClone, South Logan, UT) supplemented with 10\% FBS (Gibco, Carlsbad, CA), and $1 \%$ penicillin-streptomycin solution (Gibco). Cells were passaged every 2 days. Production and titration of pseudovirus pRABV and pVSV (an HIV backbone but expresses a vesicular stomatitis virus envelope glycoprotein) were as previously described 12 . The reason why pVSV was used as a control was that compounds inhibiting HIV replication or luciferase activity will also inhibit pRABV. Virulent rabies virus CVS strain was adapted by BSR cells and BALB/c mice, respectively, and stored at $-70^{\circ} \mathrm{C}$.

\section{Compound Library}

The 767 compounds, obtained from the National Standard Chemical Control Library of NIFDC were verified to be $>95 \%$ purity by HPLC analysis. Each compound is currently approved and marketed (as a prescription or over-the-counter medication) in China, and can be administered orally or parenterally. Each compound used in HTS was dissolved in 100\% DMSO at a concentration of $30 \mathrm{mM}$ and stored at $-20^{\circ} \mathrm{C}$.

\section{Screening Assay With Pseudovirus}

Screening was performed in 96-well plates. Eighty wells of each plate were used for test compounds, leaving the first and second columns empty for $0 \%$ inhibition (DMSO only, maximum signals $=$ positive control) and background controls, respectively. For primary screening, a stock $(30 \mathrm{mM})$ of each compound was diluted by adding $1 \mu \mathrm{L}$ of the sample to $99 \mu \mathrm{L}$ of growth media. Next, the compounds were serially diluted and incubated with $50 \mu \mathrm{L}$ of pseudovirions $\mathrm{pRABV}$ at $37^{\circ} \mathrm{C}, 5 \% \mathrm{CO}_{2}$ for $1 \mathrm{~h}$. Then the $293 \mathrm{~T}$ cells were added in 96-well plates at a density of $5 \times 10^{4}$ cells/well and incubated for $48 \mathrm{~h}$ at $37^{\circ} \mathrm{C}, 5 \%$ $\mathrm{CO}_{2}$. After incubation, $150 \mu \mathrm{L}$ of culture medium per well was discarded and $100 \mu \mathrm{L}$ of Bright-Glo luciferase reagent (Promega, Madison, WI) was added to each well and reacted with cells for $2 \mathrm{~min}$ at room temperature. Finally, $150 \mu \mathrm{L}$ of lysate per well was transferred to a solid black 96-well plate, and the luminescence signal was collected using a Glomax 96 microplate luminometer (Promega). Percent inhibition was calculated as $100 \times[1-($ RLU in the presence of compound - RLU of negative control)/(RLU of positive control-RLU of negative control)].

\section{Cytotoxicity Testing}

The $50 \%$ cytotoxic concentration $\left(\mathrm{CC}_{50}\right)$ of drugs were determined by CellTiter Glo luminescent cell viability assay kit (Promega, Madison, WI). Specifically, serial dilutions of drugs, starting from $200 \mu \mathrm{M}$ were mixed with $293 \mathrm{~T}$ cells in 96-well plates, then added $50 \mu \mathrm{L}$ complete medium instead of virus. After incubation at $37^{\circ} \mathrm{C}$ for $24 \mathrm{~h}$, the cell viability was analyzed using a microplate luminometer (Promega, Madison, WI). The $\mathrm{CC}_{50}$ was determined by the dose-response curve using nonlinear regression.

\section{Rapid Fluorescent Focus Inhibition Test (RFFIT)}

Immunogenicity determination of rabies vaccines or natural infection-elicited antibody responses against rabies virus is determined using serological assays including the rapid fluorescent focus inhibition test (RFFIT). This method is also used to verify the effect of compounds. A $100-\mu \mathrm{L}$ serial dilution of each test compound ( 9 dilutions in a 3 -fold stepwise manner) was incubated with $50 \mu \mathrm{L}$ of RABV CVS (20, $000 \mathrm{FFU} /$ well) in duplicate for $1 \mathrm{~h}$ at $37^{\circ} \mathrm{C}$. After neutralization, $50 \mu \mathrm{L}$ of BSR cells $\left(1 \times 10^{6} / \mathrm{ml}\right)$ were added into each well, then plates were 
cultured for $24 \mathrm{~h}$ in a $5 \% \mathrm{CO}_{2}$ incubator at $37^{\circ} \mathrm{C}$. Finally, cells were fixed with pre-chilled $80 \%$ acetone at $4^{\circ} \mathrm{C}$ for $30 \mathrm{~min}$ and stained with FITC-conjugated anti-rabies $\mathrm{N}$ monoclonal antibody (Fujirebio Diagnostics, Malvern, PA) at $37^{\circ} \mathrm{C}$ for $30 \mathrm{~min}$ (Smith et al., 1973). The fluorescent intensity per well was recorded visually under a fluorescence microscope (Olympus, Tokyo, Japan).

\section{Binding Affinity Assay}

The SPR analysis was performed at $25^{\circ} \mathrm{C}$ using a BIAcore S200 machine with CM5 chips (GE Healthcare). For all the analyses, PBS-P buffer consisting of $10 \mathrm{mM}$ PBS, $\mathrm{pH} 7.4$, $2.7 \mathrm{mM} \mathrm{KCl}$ and $137 \mathrm{mM} \mathrm{NaCl}, 0.05 \%$ surfactant P20 and $5 \%$ DMSO was used, and all compounds were exchanged to the same buffer in advance via gel filtration. The blank channel of the chip was used as the negative control. RABV were immobilized on the chip at about 4,800 response units. CFZ solutions at gradient concentrations of $0,0.75,1.25,2.5,5,10,20$, and $40 \mu \mathrm{M}$ were allowed to flow over the chip surface. After each cycle, the sensor surface was regenerated with 50\% DMSO. The binding kinetics was analyzed with the software of BIA evaluation Version 4.1 using a 1:1 Langmuir binding model.

\section{Time of Addition Assay}

The "time-of-addition" experiment was designed as described previously to determine the virus infection stage blocked by CFZ (Wu et al., 2019). BSR cells were seeded in 96-well plates 1 day in advance. (a) Cell receptor antagonism test: at time point $-1 \mathrm{~h}$, compound $\mathrm{CFZ}$ was added at $4^{\circ} \mathrm{C}$ for $1 \mathrm{~h}$ then washed with phosphate-buffered saline (PBS) three times. BSR cells were then infected with authentic rabies CVS strain at $4^{\circ} \mathrm{C}$ for $1 \mathrm{~h}$ then washed with PBS. (b) CVS fusion/entry test: at time point $0 \mathrm{~h}$, both compound CFZ and CVS strain were added at $37^{\circ} \mathrm{C}$ for $1 \mathrm{~h}$ and washed with PBS. (c) and (d) CVS fusion/post-entry and intracellular biosynthesis test: compound CFZ was added after being infected with CVS strain at $4^{\circ} \mathrm{C}$ or $37^{\circ} \mathrm{C}$ for 1 . The temperature was set to $37^{\circ} \mathrm{C}$ for all plates at time point $+1 \mathrm{~h}$. After incubation for another $23 \mathrm{~h}$, the inhibition rate was analyzed with Promega microplate luminometer as described previously. Wells treated with DMSO only were used as controls. Data was analyzed based on three independent replicates.

\section{Fusion Assay}

The fusion activity of Rabies virus was determined by counting the number of lyzed cells after the cells were infected. Briefly, 293T cells were first cultured into monolayers in a 24-well plate. Each well was transfected with plasmid pCMV-CVS (Nie et al., 2017). After incubation at $37^{\circ} \mathrm{C}$ and $5 \% \mathrm{CO}_{2}$ incubator for $24 \mathrm{~h}$, the medium was replaced by fusion medium buffered with $\mathrm{HCl}$ to $\mathrm{pH} 5.0$ for $15 \mathrm{~min}$. The numbers of cells with and without membrane fusions in each well were counted under a microscope, and the data was calculated using ImageJ; at least five wells were counted for each virus sample. Results were derived from two independent assays.

\section{Molecular Modeling Analysis}

The 2D structures of the drugs were downloaded from PubChem database by name, or drawn using ChemDraw software. Discovery Studio 4.5 software (Accelrys Software Inc., San Diego, CA, United States) was used to convert each 2D structure to a $3 \mathrm{D}$ molecular model, and the "Prepare Ligands" module was used to add hydrogen atoms and perform energy optimization operations.

\section{General Procedure for the Preparation of CFZ Salts}

CFZ (100 mg, $0.21 \mathrm{mmol})$, salt-forming acid $(0.21 \mathrm{mmol})$ and three drops of acetonitrile were ground in a mortar-pestle for $1 \mathrm{~h}$ to give of the desired salt. Clofazimine salicylates (CFZS) $\mathrm{mp}$ $243-245^{\circ} \mathrm{C}$; Clofazimine hydrochloride salt (CFZH) mp $254-256^{\circ} \mathrm{C}$; Clofazimine gallic acid salt (CFZG) mp $177-179^{\circ} \mathrm{C}$; Clofazimine aspirin salt (CFZA) mp $238-240^{\circ} \mathrm{C}$; Clofazimine methanesulfonate (CFZM) mp $253-255^{\circ} \mathrm{C}$.

\section{Animal Experiments}

Mice were handled in accordance with institutional (NIFDC, Beijing, China) guidelines for laboratory animal care and use, and the Animal Care and Use Committee at the NIFDC approved the study protocol. CFZ, Clofazimine salts and T-705, the positive control, were dissolved in $0.5 \%$ methylcellulose (Sigma-Aldrich, St. Louis, MO) and administered by oral gavage at $300 \mathrm{mg} / \mathrm{kg} /$ day based on earlier studies (Yamada et al., 2016; Yamada et al., 2019). Female BALB/c mice ( $\mathrm{n}=8-10$ per group) were intramuscularly (IM) inoculated in the left hind limb with $100 \mu \mathrm{L}$ of Rabies virus CVS strain $\left(3.8 \mathrm{lg} \mathrm{LD}_{50} / \mathrm{mL}\right)$. Next, infected mice were orally administered once daily, starting at $1 \mathrm{~h}, 1$ day, 2 days, or 4 days after infection. Animals were monitored and weighed for up to 14 days post-challenge or until death. Mice were considered to be sick when clinical signs, such as significant weight loss (a $2 \mathrm{~g}$ reduction from the day before), secretion around eyes, a foot slip on a stainless-steel wire top clip of a mouse cage, and/or paralyses, were observed.

\section{Statistical Analysis}

GraphPad Prism 6 (San Diego, CA) was used to determine $\mathrm{EC}_{50}$ and $\mathrm{CC}_{50}$ values of compounds. Statistical significance of percent survival was determined by log-rank (Mantel-Cox) and $\chi$ (Davis et al., 2015) tests. $p$ values of $<0.05$ were considered statistically significant.

\section{RESULTS}

\section{High-Throughput Assay Using Pseudotyped RABV Virus and Authentic RABV CVS Strain} Pseudovirus containing a firefly luciferase reporter gene enveloped by the RABV glycoprotein G (pRABV) was used for HTS to select inhibitors of viral entry. HTS conditions including cell-seeding density and pRABV dose were optimized as 50,000 cells/well and $1500 \quad \mathrm{TCID}_{50} /$ well, respectively. Under these conditions, the signal-to-basal (S/B) 

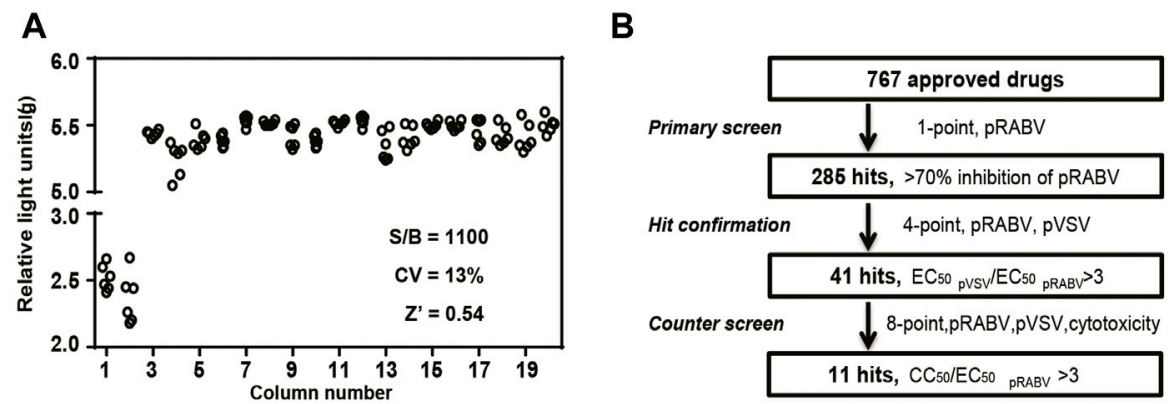

\section{C}
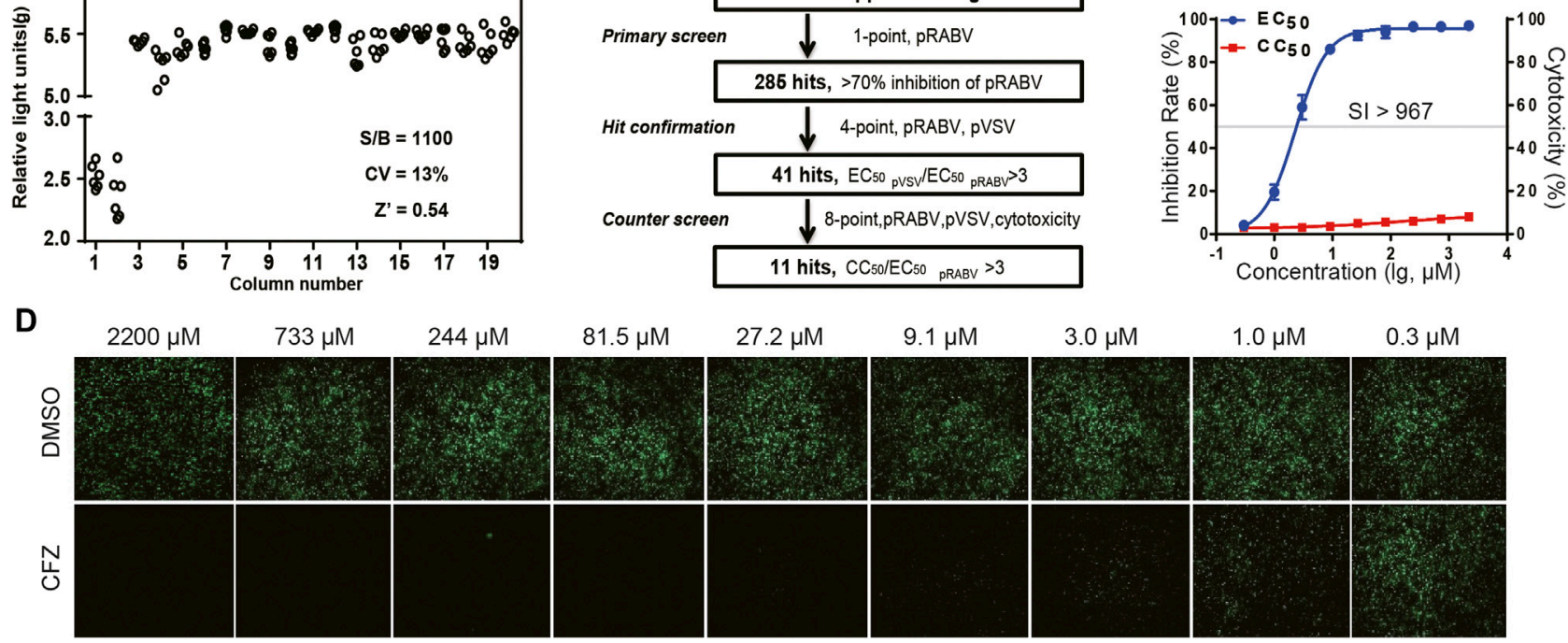

FIGURE 1| HTS for inhibitors of RABV from 767 compounds. (A) Scatter plot of results from DMSO plate screening. Wells in columns 1 and 2 of the 96 -well assay plates contained 293Tcells as a control (0\% response), whereas pseudotyped RABV (pRABV) was added to all other wells (positive control, $100 \%$ response). The signalto-basal ratio (S/B) in this plate was 1100 -fold, with a CV of $13 \%$ and Z' factor of 0.54 . (B) HTS assay flow chart using pRABV. (C). Inhibition rate of CFZin the RFFIT assay is shown in blue, and cytotoxicity of compounds on host cells is shown in red. (D). The RFFIT assay of CFZ.

TABLE 1 | Anti-RABV activity of 11 hit compounds.

\begin{tabular}{|c|c|c|c|c|c|c|c|c|c|}
\hline Compounds & $\begin{array}{l}\mathrm{CC}_{50} \\
(\mu \mathrm{M})^{\mathrm{a}}\end{array}$ & $\begin{array}{c}\text { pRABV } \\
\text { EC }_{50} \\
(\mu \mathrm{M})\end{array}$ & $\begin{array}{c}\text { SI } \\
\text { pRABV }\end{array}$ & $\begin{array}{l}\text { pVSV } \\
\mathrm{EC}_{50} \\
(\mu \mathrm{M})\end{array}$ & $\begin{array}{l}E C_{50} p V S V / \\
E_{50} p R A B V\end{array}$ & $\begin{array}{l}\text { CVS } \\
\mathrm{EC}_{50} \\
(\mu \mathrm{M})\end{array}$ & $\mathbf{S I}_{\mathrm{cvs}}$ & $\begin{array}{l}\text { Approved } \\
\text { indication }\end{array}$ & $\begin{array}{l}\text { Mode } \\
\text { of action }\end{array}$ \\
\hline Clofazimine & $>200$ & 1.7 & $>120$ & 10.5 & 6.3 & 2.28 & $>87.9$ & Antileprotic & DNA replication inhibitor \\
\hline Pizotifen & 100.5 & 3.1 & 32.3 & 25.7 & 8.2 & 67.0 & 1.5 & Antimigraine & Serotonin antagonist \\
\hline Amlodipine besylate & 36.3 & 1.4 & 26.8 & 26.4 & 19.4 & 37.4 & 1.0 & Antihypertensive & Calcium channel blocker \\
\hline Amodiaquine hydrochloride & 84.9 & 4.2 & 20.3 & 24.3 & 5.8 & 14.8 & 5.7 & Antimalarial & $\begin{array}{l}\mathrm{N} \text {-desethylamodiaquine } \\
\text { activator }\end{array}$ \\
\hline Ketotifen fumarate & $>200$ & 10.8 & $>18$ & 87.8 & 8.1 & 67.0 & $>3.0$ & Antiallergic & $\mathrm{H} 1$-antihistamine stabilizer \\
\hline Amlodipine maleate & 34.9 & 1.9 & 17.9 & 25.8 & 13.3 & 37.8 & 0.9 & Antihypertensive & Calcium channel blocker \\
\hline Maprotiline hydrochloride & 52 & 6.9 & 7.5 & 32.5 & 4.7 & 44.2 & $>4.5$ & Antidepressant & H1 receptor antagonist \\
\hline Irinotecan hydrochloride & $>200$ & 33.6 & $>5.9$ & $>200$ & $>5.9$ & 67.0 & 1.2 & Anticancer & Topoisomerase I inhibitor \\
\hline $\begin{array}{l}\text { Dioxopromethazine } \\
\text { hydrochloride }\end{array}$ & $>200$ & 36.7 & $>5.5$ & $>200$ & $>5.5$ & 67.0 & $>3.0$ & Antipsychotic & Dopamine receptor antagonist \\
\hline Cisplatin & $>200$ & 39.1 & $>5.1$ & $>200$ & $>5.1$ & 67.0 & $>3.0$ & Anticancer & DNA replication inhibitor \\
\hline Tetracaine hydrochloride & $>200$ & 65.8 & $>3$ & $>200$ & $>3$ & 67.0 & $>3.0$ & Anesthetic & Calcium channel blocker \\
\hline
\end{tabular}

A highest concentration of inhibitors evaluated for cytotoxicity assays was $200 \mu \mathrm{M}$.

ratio, coefficient of variation $(\mathrm{CV})$ value, and $\mathrm{Z}$ ' factor were 1,100 , $13 \%$, and 0.54 , respectively (Figure $\mathbf{1 A}$ ), indicating that the experimental requirements are met.

To search for potent inhibitors against RABV, we screened a chemical library composed of 767 approved drugs, as shown in Figure 1B. The primary screen at a single dosage $(200 \mu \mathrm{M})$ indicated that 285 hit compounds had $>70 \%$ inhibition, thus necessitating a second round of confirmation. As compounds inhibiting HIV replication or luciferase activity will also inhibit pRABV, pVSV with the same HIV backbone but expressing a vesicular stomatitis virus envelope glycoprotein was used to carry out the second round of screening in parallel. Each of the 285 compounds was diluted at a 1:3 ratio to generate four concentrations ranging from 200 to $7.4 \mu \mathrm{M}$ to determine their $\mathrm{EC}_{50}$ values against $\mathrm{pRABV}$ and $\mathrm{pVSV}$. When $\mathrm{EC}_{50} \mathrm{pvsv} / \mathrm{EC}_{50}$ pRABV ratio was $>3$, the compound was identified as positive. Thus, 41 compounds were confirmed to block pRABVmediated infection specifically with little to no effect on pVSV infectivity. Meanwhile, the cytotoxicity of 41 compounds was also detected, and the ratio of $\mathrm{CC}_{50}$ and $\mathrm{EC}_{50} \mathrm{pRABV}$ was calculated as a selectivity index (SI). After final screening, 11 compounds were confirmed to possess 


\section{A}

RU

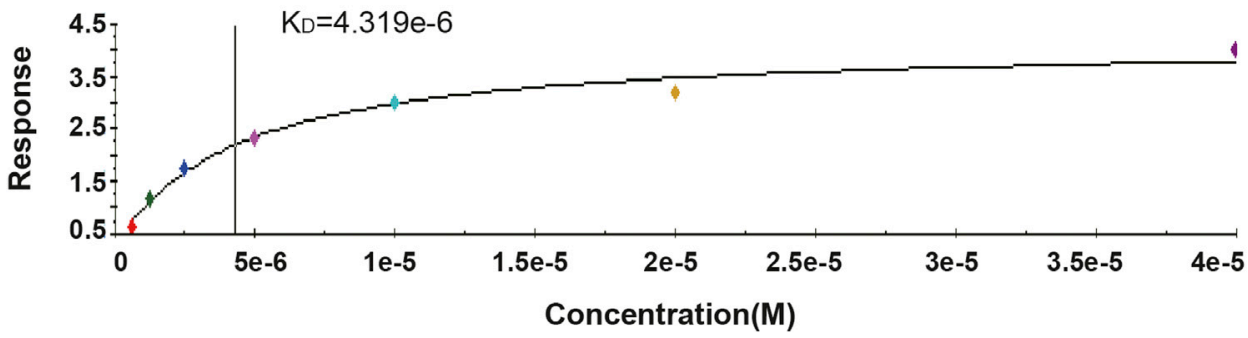

B

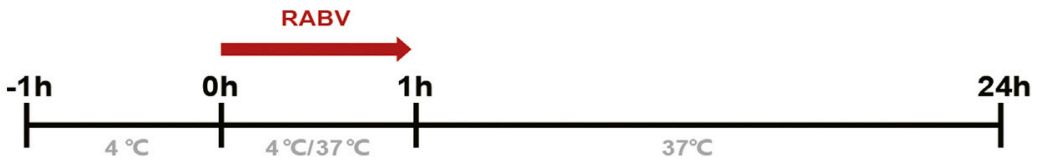

(a) $-1 \mathrm{~h}, 4^{\circ} \mathrm{C}$

(b) $0 \mathrm{~h}, 37^{\circ} \mathrm{C}$

(c) $+1 \mathrm{~h}, 4^{\circ} \mathrm{C}$

(d) $+1 \mathrm{~h}, 37^{\circ} \mathrm{C}$

C

(a) $-1 \mathrm{~h}, 4^{\circ} \mathrm{C}$
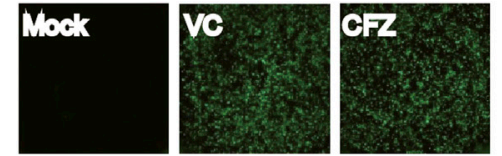

(b) $0 \mathrm{~h}, 37^{\circ} \mathrm{C}$
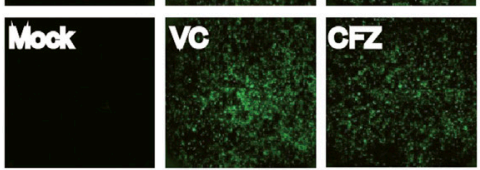

(c) $+1 \mathrm{~h}, 4^{\circ} \mathrm{C}$
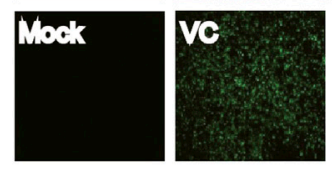

Cr2
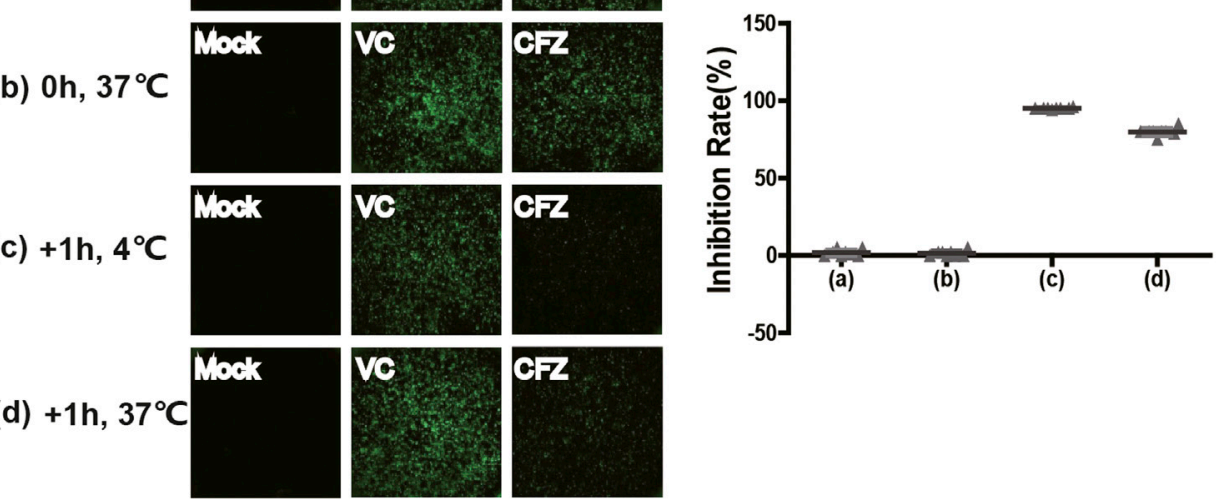

FIGURE 2 | Anti-RABV mechanisms of CFZ. (A) Binding of RABV and CFZ by BIAcore assay. (B) Schematic diagram of the "time-of-addition". Blue arrows show the period when CFZ was present. Red arrows show the period when RABV CVS strain was present. (C) Inhibition of RABV infection was detected as a decrease in fluorescence activity. Inhibition rates of RABV infection were presented on the right.

good efficacy against pRABV and exhibited low cytotoxicity, with SI value of above 3 (Table $\mathbf{1}$ ).

To verify results obtained from HTS, we next examined the antiviral activity of 11 hits with an authentic RABV CVS strain using the RFFIT method (Table 1). The compounds were diluted at a $1: 3$ ratio to generate nine concentrations ranging from 2,200 to $0.3 \mu \mathrm{M}$. Clofazimine (CFZ) was found to be efficacious against CVS with an $\mathrm{EC}_{50}$ value of $2.28 \mu \mathrm{M}$, and a low level of cytotoxicity (SI of >967) (Figure $1 \mathrm{C}$ and D). CFZ is a riminophenazine that used for the treatment of leprosy and tuberculosis (Lu et al., 2011; Cholo et al., 2012; Liu et al., 2012; Murashov et al., 2018).

\section{Binding Affinity Assay and Time-Of-Addition Effect of CFZ on RABV Life Cycle}

To better understand how CFZ acted on RABV, the binding affinity and kinetics of CFZ was determined by SPR at $25^{\circ} \mathrm{C}$. Under the conditions tested, the binding affinity $\left(\mathrm{K}_{\mathrm{D}}\right)$ of CFZ to RABV was $4.319 \mu \mathrm{M}$ (Figure 2A). These initial results suggested a 


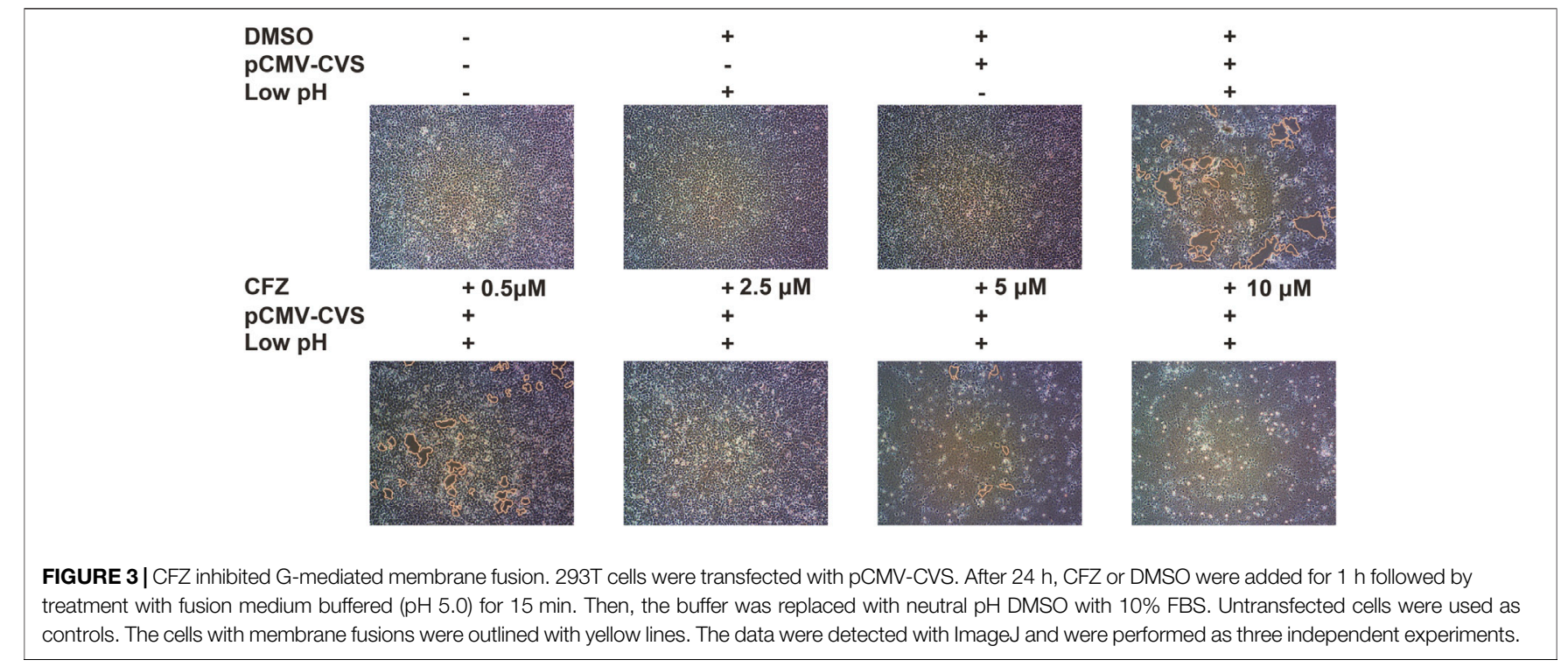

possible link between CFZ and RABV. Furthermore, the "timeof-addition" experiment was performed to elucidate which step of viral replication was inhibited by CFZ (Figure 2B). CFZ $(25 \mu \mathrm{M})$ was added to BSR cells before authentic RABV CVS strain infection $(-1 \mathrm{~h})$, during infection $(0 \mathrm{~h})$, and $1 \mathrm{~h}$ post infection $(+1 \mathrm{~h})$ and incubated for $1 \mathrm{~h}$. Control wells were treated with compound vehicle (DMSO). All assays were performed in octuple. As shown in Figure 2C, no suppression of fluorescence activity by CFZ was observed at $-1 \mathrm{~h}$ or $0 \mathrm{~h}$ point, suggesting that CFZ did not inhibit RABV infection either by directly binding to RABV or blocking the cell receptors. However, CFZ exerted a strong inhibitory effect when added $1 \mathrm{~h}$ post infection both at 4 and $37^{\circ} \mathrm{C}$, suggesting that $\mathrm{CFZ}$ worked on viral membrane fusion and genome replication.

\section{CFZ Inhibits G-Mediated Membrane Fusion}

G-mediated membrane fusion is a common condition which has considerable impact on a low-pH. In order to confirm whether CFZ could inhibit RABV infection at a membrane fusion step, a glycoprotein G-mediated membrane fusion assay was designed. $293 \mathrm{~T}$ cells transfected with pCMVCVS, a plasmid expressing CVS glycoprotein G, were incubated with either compound and subjected to a low-pH pulse to promote fusion. As shown in Figure 3, low $\mathrm{pH}$ triggered membrane fusion in pCMV-CVS-transfected cells, whereas a neutral $\mathrm{pH}$ showed no effect. CFZ significantly inhibited syncytium formation at concentration of $10 \mu \mathrm{M}$. These results indicated that blockade of glycoprotein G-mediated membrane fusion was one mechanism underlying CFZ inhibition of RABV infection. CFZ may also inhibit RABV infection by impacting infected host cells, for example by modulating host potassium channels or by inducing the generation of reactive oxygen species within these cells (Cholo et al., 2012; Leanza et al., 2014; Faouzi et al., 2015).

\section{Molecular Docking of CFZ With RABV Glycoprotein G}

To investigate their interaction, LibDock docking (including and CDOCKER analyses) was performed for CFZ and RABV glycoprotein G. The co-crystal structure (Protein Data Bank ID: 3NKF) of PTPN4 PDZ domain complexed with the C-terminus of a rabies virus $G$ protein was selected to be the receptor model. CFZ displayed a reasonable LibDock score of 120.362, indicating a good interaction between CFZ and RABV glycoprotein $\mathrm{G}$. In addition, the interaction binding energy of $33.0582 \mathrm{kcal} / \mathrm{mol}$, indicated direct interaction between CFZ and RABV glycoprotein G. CFZ fitted well in the active binding site of RABV glycoprotein G (Figure 4), and the major interactions included hydrogen bond, van der Waals forces, Pi-cation and hydrophobic interaction, might contribute together to the strong interactions (Figure 4). The docking configuration is merely suggestive and needs extensive experimental validation.

\section{Anti-RABV Activity of Clofazimine Salts in vitro and in vivo}

There were obvious side effects of pigmentation in skin when CFZ was used in the treatment of leprosy, originating from its high lipid solubility. Therefore, five different CFZ salts including CFZA, CFZS, CFZH, CFZM, and CFZG were prepared in equal molar ratio to improve the pharmacokinetic and pharmacodynamic property (Figure 5A). Then, the antiviral activity and cytotoxicity of these salts were examined using CVS, as described previously. The calculated $\mathrm{EC}_{50}$ values, solubility, and lipid/water distribution coefficient (ClogP) values for CFZA, CFZS, CFZH, CFZM, and CFZG are shown in Figure 5B. CFZS, CFZA and CFZH were the most potent inhibitors of RABV infection with $\mathrm{EC}_{50}=1.2 \mu \mathrm{M}$.

Most of these clofazimines salts exhibited higher anti-RABV activity, improved solubility as well as lower lipophilicity on the 


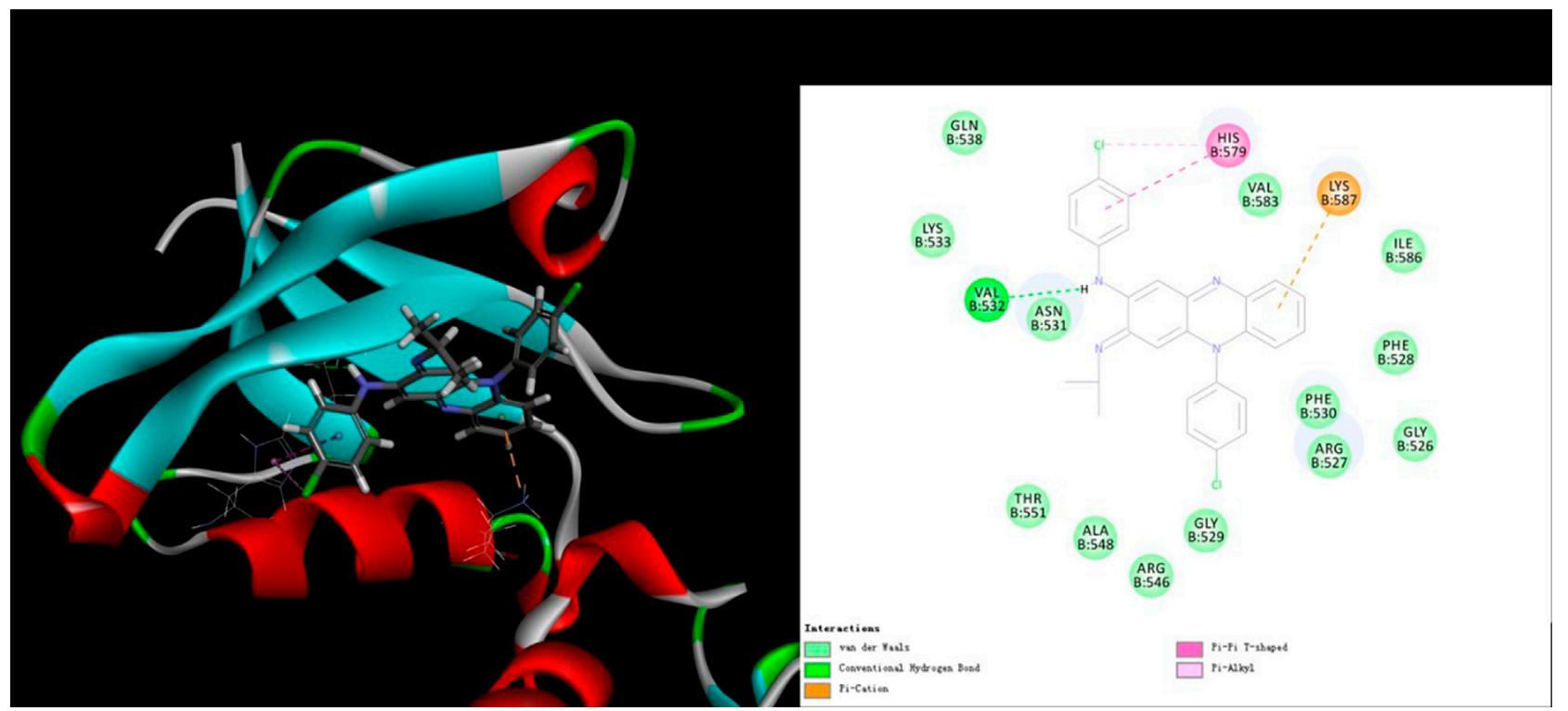

FIGURE 4 | Receptor-ligand interaction model of CFZ with RABV glycoprotein G by CDOCKER calculation. (Left) Solid surface map of the interaction pocket with CFZ. Red, blue, and white colored regions correspond to negatively charged, positively charged, and neutral areas, respectively. (Right) Ligand is colored by element type (C, yellow; N, blue; Cl, green), key bonds are indicated by dashed lines between the atoms involved, and the colors of key bonds and residues are shown according to the interaction mode (van der Waals, light green; hydrogen bond, green; Pi-cation, orange; Pi-sigma, purple and Pi-alkyl, mauve pink).

basis of CFZ, indicating that the salt forming modification of CFZ might be beneficial for the antiviral potency enhancement because of the physicochemical property improvement.

To further confirm antiviral activity, we evaluated the treatment effects of CFZ and CFZ salts in a murine infection model using the CVS strain, which was administered intramuscularly. IM administration allowed a longer incubation period and relatively slow symptom appearance, which was conducive to investigate the preventive effects of treatment after exposure. In this model, the virus enters the brain through peripheral nerves and then proliferates massively in the central nervous system. Infected mice first lose hair luster and then develop flaccid paralysis, which extends from the hind limbs to the whole body. In our study, weight loss and quadriplegia were considered as indices of disease. Balb/c mice due to their small size and convenience to study are more suitable than golden hamsters and beagle dogs for large-scale screening. CFZ (150 mg/kg), CFZA (207 mg/kg), CFZS (194 mg/kg), CFZH $(162 \mathrm{mg} / \mathrm{kg})$, CFZM $(181 \mathrm{mg} / \mathrm{kg})$, and CFZG $(204 \mathrm{mg} / \mathrm{kg})$ were orally administered $1 \mathrm{~h}$ after IM inoculation of virus. Mice were treated once daily for 7 days and monitored for a total of 14 days after virus exposure.

As shown in Figure 5C, untreated BALB/c mice were observed to be sick and they died on the fifth and eighth day post infection (dpi), respectively. Overall, the mortality was $100 \%$ for the control group, and all of the sick mice were dead by $10 \mathrm{dpi}$. CFZ, CFZA, and CFZS improved the overall survival rates of mice infected with CVS compared with controls; there was still a tendency of CFZ, CFZS, and CFZG to delay the onset time of symptoms and prolong survival. At five dpi, percentages of sick mice in control, CFZ, CFZS, and CFZG treatment groups were 80, 50, 40, and
$40 \%$, respectively. Moreover, at $14 \mathrm{dpi}$, survival rates in CFZ, CFZA, and CFZS treatment groups were, 10, 25, and 30\%, respectively. In contrast, CFZH, CFZM, CFZG produced no improvement on the survival rate compared with the control. No redness in the skin was observed in mice treatment with clofazimine salts compared with CFZ. Although the physicochemical properties of CFZS, the most efficacious compound, predict higher permeability of the blood-brain barrier and lower accumulation in adipose tissue, future pharmacokinetic studies will have to be performed to verify these predictions.

\section{CFZS Exhibited Superior anti-RABV Activity Than T-705 When Administered one or 2 days Post-challenge}

Given the encouraging effect of CFZS, we designed an additional experiment to evaluate the antiviral efficacy of CFZ and CFZS upon initiation of administration at different time points post-exposure. Favipiravir (also known as T-705) was used as the positive control because it was efficacious in mouse models of RABV infection when administered at $300 \mathrm{mg} / \mathrm{kg} /$ day $1 \mathrm{~h}$ after viral inoculation (Yamada et al., 2016; Yamada et al., 2019). In this experiment, mice intramuscularly inoculated with RABV CVS strain were orally administered T-705 $(300 \mathrm{mg} / \mathrm{kg})$, CFZ $(150 \mathrm{mg} / \mathrm{kg})$ and CFZS $(194 \mathrm{mg} / \mathrm{kg})$ beginning at different time points. Mice were monitored for 14 days and the Kaplan-Meier survival curves were shown for individual studies with appropriate vehicle controls.

T-705 treatment $(300 \mathrm{mg} / \mathrm{kg} /$ day $)$ started $1 \mathrm{~h}$ or $24 \mathrm{~h}$ after RABV CVS infection resulted in $40 \%$ survival at $14 \mathrm{dpi}$, while 10 and $0 \%$ mice survived when treatment was started 48 and $96 \mathrm{~h}$ 
A<smiles>CC(C)N=c1cc2n(-c3ccc(Cl)cc3)c3ccccc3nc-2cc1Nc1ccc(Cl)cc1</smiles>

CFZ<smiles>CC(=O)Oc1ccccc1C(=O)O</smiles>

Aspirin<smiles>CS(=O)(=O)O</smiles>

Methanesulfonic acid<smiles>O=C(O)c1ccccc1O</smiles>

$\mathrm{HCl}$

Salicylic acid Hydrochloride<smiles>O=C(O)c1cc(O)c(O)c(O)c1</smiles>

Gallic acid

B

\begin{tabular}{ccccc}
\hline & $\begin{array}{c}\mathrm{EC}_{50} \\
(\mu \mathrm{M})\end{array}$ & $\begin{array}{c}\text { Dissolution } \\
(50 \mathrm{mg})\end{array}$ & $\begin{array}{c}\text { Solubility } \\
(\mu \mathrm{g} / \mathrm{mL})\end{array}$ & $\mathrm{C} \log \mathrm{P}$ \\
\hline $\mathrm{CFZ}$ & 2.28 & 531.38 & 0.29 & 0.990 \\
\hline CFZA & 1.20 & 1740.57 & 4.00 & 0.199 \\
$\mathrm{CFZS}$ & 1.20 & 2397.37 & 0.86 & 0.248 \\
\hline CFZH & 1.20 & 2300.00 & 7.66 & 0.443 \\
CFZM & 2.50 & 3087.21 & 18.34 & 0.475 \\
CFZG & 2.07 & 2110.70 & 43.60 & 0.614 \\
\hline
\end{tabular}
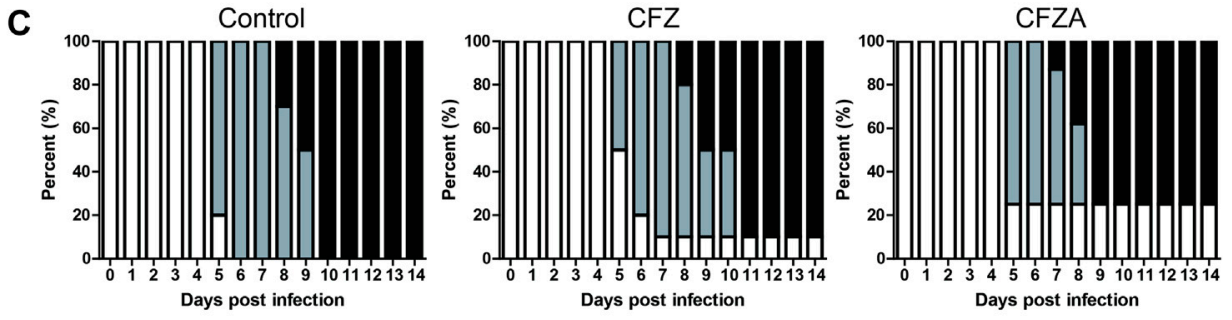

CFZS

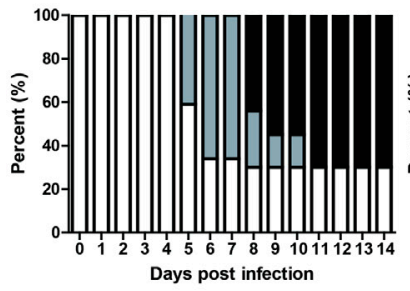

$\mathrm{CFZH}$

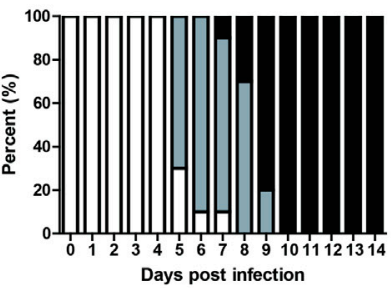

CFZM

CFZG
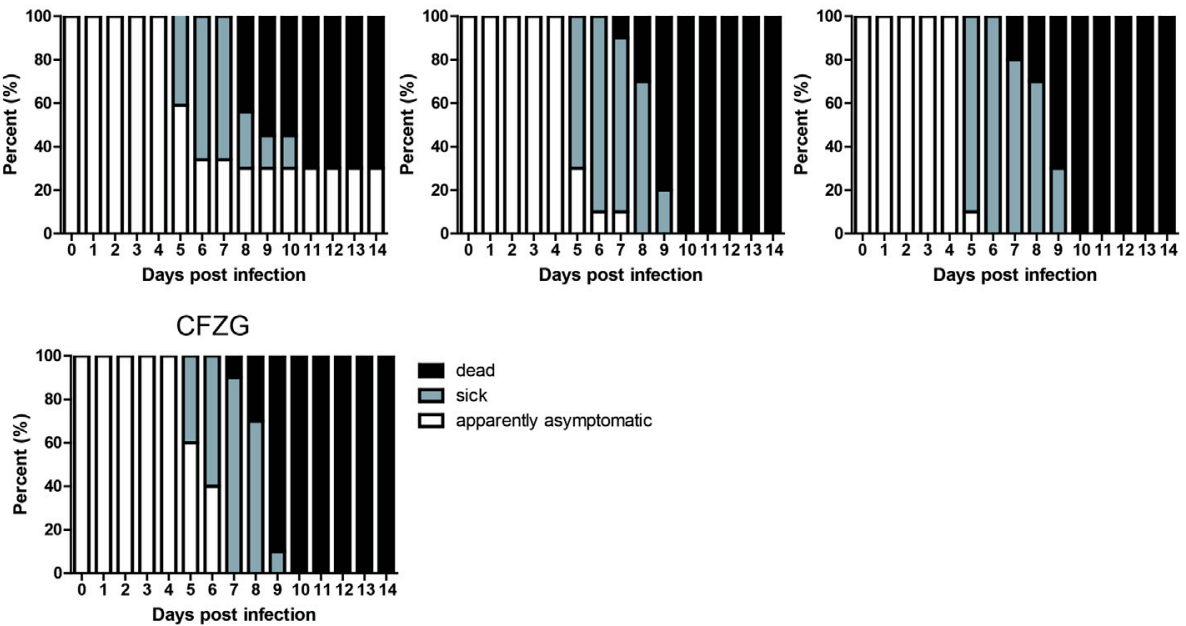

FIGURE 5 | Anti-RABV activity of five Clofazimine salts in vitro and in vivo. (A) Structure of Clofazimine and other five Clofazimine salts. (B). EC50s, dissolutions, solubilities, and ClogPs of Clofazimine and other Clofazimine salts. (C). The survival curves of mice treatment with different compounds. Mice were intramuscularly inoculated with RABV and orally administered CFZ (150 mg/day), CFZA (207 mg/day), CFZS (194 mg/day), CFZH (162 mg/day), CFZM (181 mg/day), and CFZG (204 mg/day), respectively, for 7 days beginning 1 day after inoculation. Mice were monitored for 14 days "Sick" indicates that mice had significant clinical signs. Log-rank test was used for comparison survival curves. The data a presented as three independent experiments. 
A

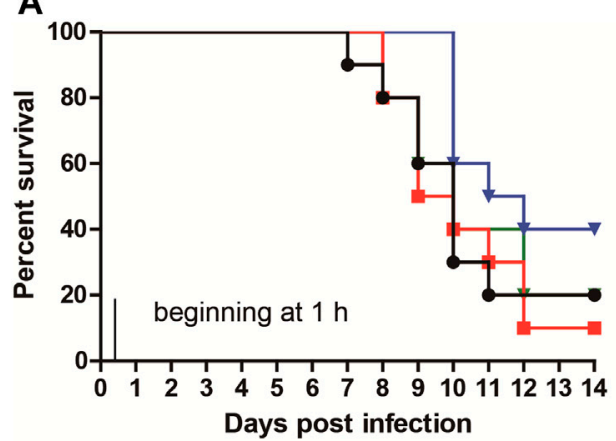

C

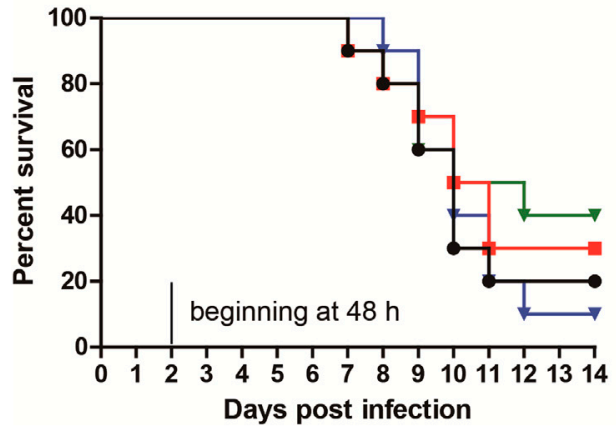

B
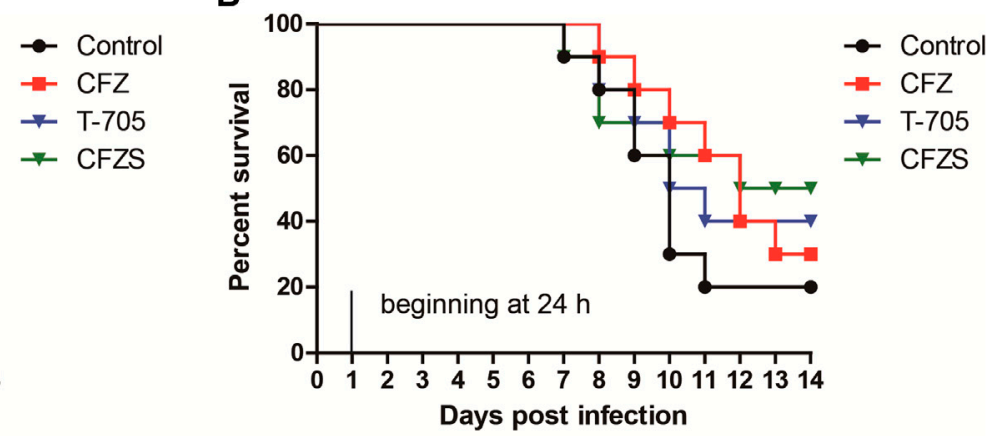

D

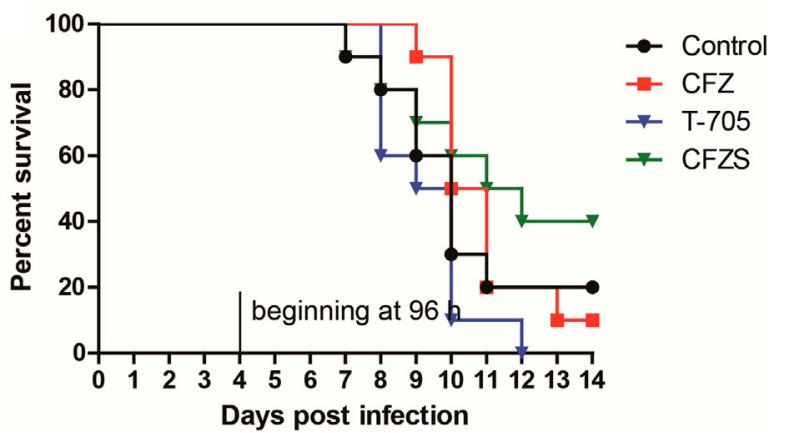

FIGURE 6 | Post-RABV challenge effect of CFZ, CFZS and T-705 on the survival rate of mice. Mice were orally administered CFZ (150 mg/kg/day), CFZS (194 mg/kg/day) or T-705 (300 mg/kg/day) beginning $1 \mathrm{~h}$ (0 days) (A), 1 day (B), 2 days (C), or 4 days (D) after inoculation and ending at 6 days (A) or 7 days (B-D) after inoculation.

after infection (Figures 6A-D). Our results corroborate earlier reports (Yamada et al., 2016; Yamada et al., 2019). We did not try higher doses of T-705 (600 or $900 \mathrm{mg} / \mathrm{kg} /$ day) that had been reported to suppress viral replication in the CNS when treatment was started $48 \mathrm{~h}$ after infection (Yamada et al., 2019).

Compared with T-705, CFZ and CFZS showed different results for optimal administration time. CFZ administration beginning at $1 \mathrm{~h}$ or $96 \mathrm{~h}$ post-challenge both did not show any antiviral efficacy. However, CFZ groups treated beginning at $24 \mathrm{~h}$ or $48 \mathrm{~h}$ post-challenge exhibited a modest increase in survival. The survival rates of both groups were $30 \%$, which was $10 \%$ higher than vehicle control $(p=0.2534$, and $p=0.5326$, respectively). CFZS administration beginning at 24,48 or $96 \mathrm{~h}$ post-challenge exhibited superior anti-RABV activity than T-705, with survival rates of 50,40 , and $40 \%$, respectively $(p=0.7462, p=$ 0.3258 , and $p=0.0388$, respectively). No redness in the skin was observed in mice treatment with CFZS.

\section{Anti-RABV Activities of CFZ and CFZS in a Neuronal Cell Line}

Since RABV is a neurotropic virus, it is essential to show that potential therapeutics suppress RABV infection in nervous tissue. We therefore used the cat astrocytoma cell line PG-4 and the in vitro RFFIT assay to assess CFS and CFZS. Both compounds showed anti-rabies virus activity in PG-4 cells with $\mathrm{EC}_{50}$ values of 4.243 and $4.706 \mu \mathrm{M}$, respectively (Figure 7).

\section{DISCUSSION}

At present, there are still no effective treatments targeting for rabies patients with clinical symptoms. A few rabies patients were cured by Milwaukee protocol, but the therapy yield positive results in about 40 cases in the following years (Willoughby et al., 2005; Brazilian Rabies Survivor, 2008; Wiedeman, 2012). Importantly, the high cost and continuous cold chain transportation of rabies vaccine and RIG has made the development of RABV-specific inhibitors pertinent. In recent years, researchers have focused on "drug repurposing", that is, exploring new pharmacological targets for old drugs. Since studies into the tolerance, delivery characteristics and kinetics of these old drugs are already available, the drugs can be used more effectively and safely. Moreover, compared with traditional new drug development, drug repurposing takes less time and cost (Ulferts et al., 2016; Wang et al., 2017). Thus, the scope of this paper lies in screening hundreds of FDA approved compounds for RABV-specific antiviral activity and identifying the specific hits, so that they can be brought to the clinic.

The current assays for immunogenicity determination of rabies vaccines or natural infection-elicited antibody responses against rabies virus are determined using serological assays including the rapid fluorescent focus inhibition test (RFFIT), fluorescent antibody virus neutralization (FAVN) test and enzyme linked immunosorbant assay (ELISA) (Smith et al., 1973). Currently, the "gold standard" for in vitro assays are 


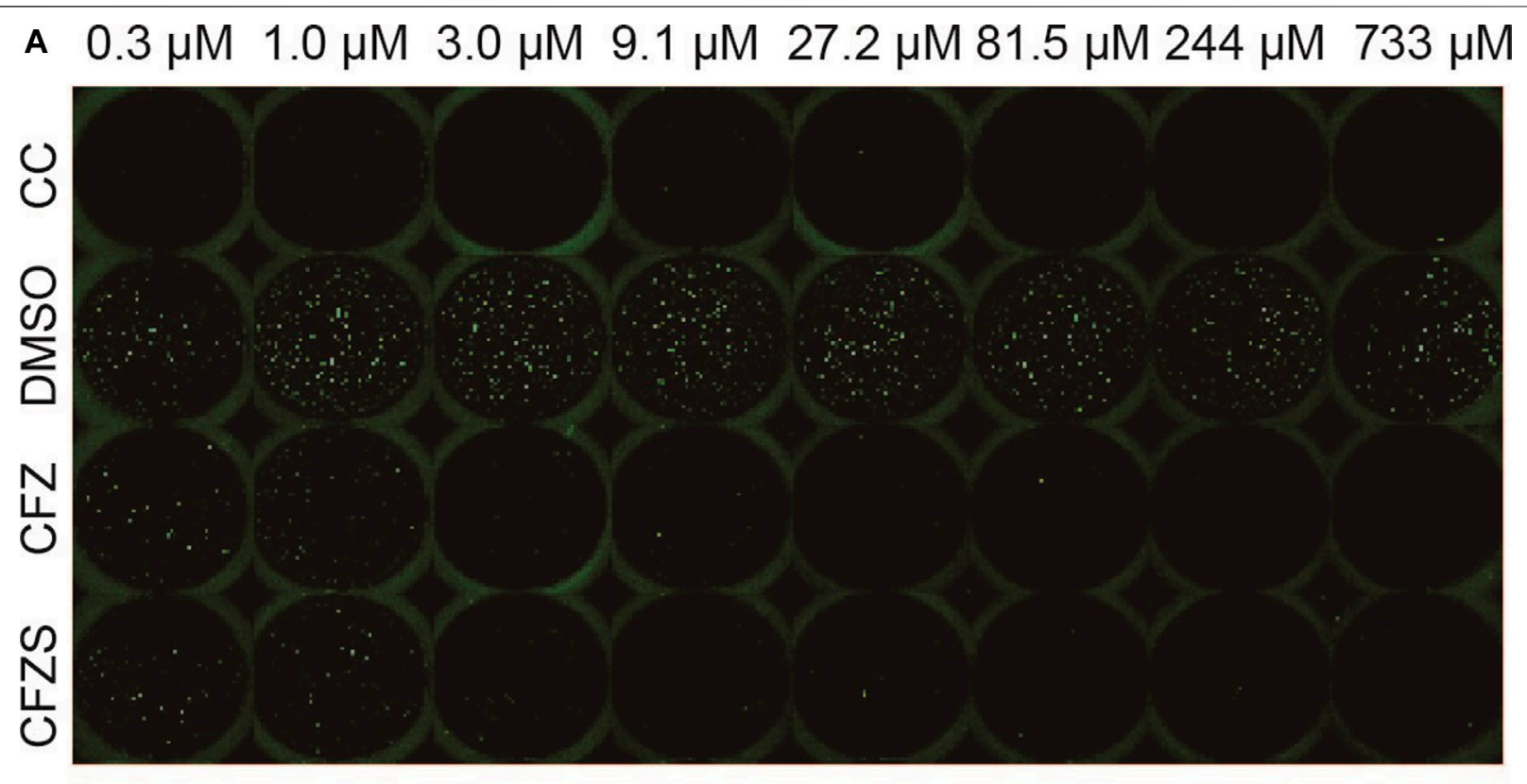

B

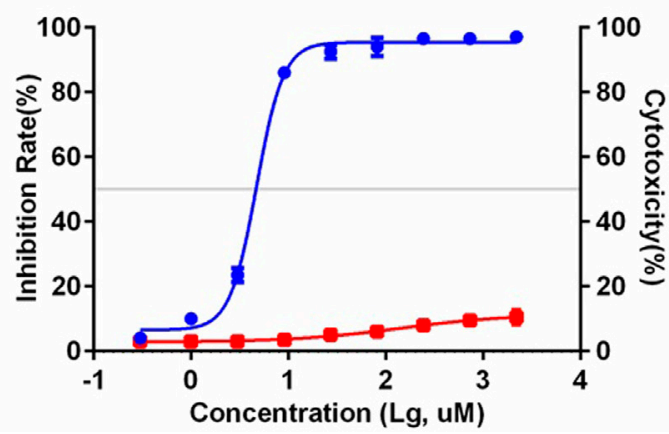

C

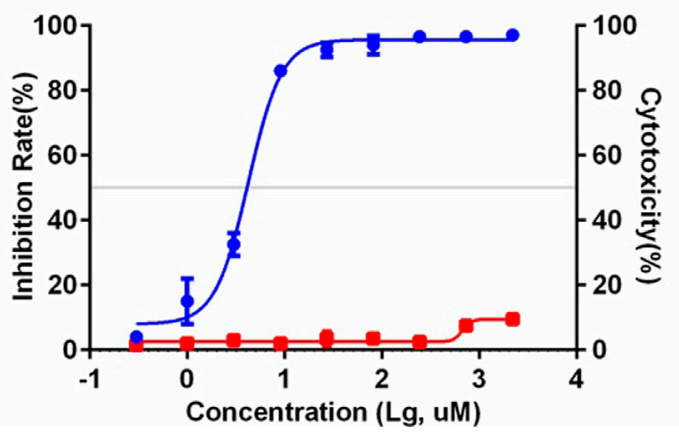

FIGURE 7 | Anti-RABV activities of CFZ and CFZS in PG-4 cells. The RFFIT assay and EC 50 of CFZ (A, B) and CFZS (A, C) in PG-4 cells.

RFFIT and FAVN, both of which are routinely used in WHO reference laboratories. Our group established a RABVneutralizing antibody assay based on $\mathrm{pRABV}$ and compared it with the RFFIT assay to define an optimal method based on criteria of simplicity, speed, and sensitivity (Wu et al., 2019). Here, the pseudovirus system was used to establish a highthroughput assay for anti-RABV drug screening. By incorporating an appropriate reporter gene, pseudotyped viruses were made amenable to HTS assay formats, which saves washing steps, time for fixation, and antibody incubation compared with the RFFIT assay. Moreover, replication-defective pseudotyped viruses allow for testing at lower biological containment facilities, enabling the use of stateof-the-art robotics platforms to assess efficacy of multiple concentrations of each compounds for hit confirmation (Basu et al., 2010).

Based on HTS of 767 compounds, we identified 11 candidates exhibiting antiviral activity against $\mathrm{pRABV}$, and then were confirmed by authentic RABV. Of the 11 candidates, CFZ, the first-line drug for the treatment of leprosy (Browne et al., 1981), had a strong inhibition of RABV activity in vitro, with $\mathrm{EC}_{50}$ of $2.276 \mu \mathrm{M}, \mathrm{CC}_{50}>2,200 \mu \mathrm{M}$, and $\mathrm{SI}>967$. The results were replicated in PG-4, a cat astrocytoma cell line, to verify the activity of CFZ and CFZS (Figure 7). Generally, the replication of RABV goes through the following stages: adsorption, penetration, shelling, transcription, translation, replication, assembly, and budding release. At a low $\mathrm{pH}$ (below 6.2), RABV enters the host cells relying on a glycoprotein G-mediated membrane fusion.

The results of the affinity analysis, time-of-addition assay, and fusion analysis in the present study indicated that CFZ inhibited RABV infection at the fusion step. Our mechanistic studies indicated that blockade of glycoprotein G-mediated membrane fusion was one mechanism underlying CFZ inhibition of RABV infection at the fusion step, although we could not exclude direct effects of CFZ on the infected host cell. 
It was worth noting that CFZ had been reported to block potassium channels (Leanza et al., 2014; Faouzi et al., 2015). This blocking of potassium channels in infected cells would change the membrane potential and alter calcium signaling, and could thereby hinder viral membrane fusion and genome replication. Because of its high lipophilicity and redox potential, CFZ was also considered to cause the production of superoxide and hydrogen peroxide (Cholo et al., 2012). In infected cells, this reactive oxygen species may inhibit viral membrane fusion and genome replication. For the neurotropic virus such as $\mathrm{RABV}$, the virus infection is a complex process in vivo. These initial steps in characterizing the antiviral activity of CFZ and CFZS should be followed up with additional studies such as identification of the drug target. Further studies are needed to define the mechanisms by which CFZ and CFZS inhibit RABV infection both in vitro and in vivo.

CFZ, a drug used for the treatment of leprosy and tuberculosis, belongs to the class 2 of biopharmaceutical classification system (BCS), which is characterized by low solubility and high permeability (Cholo et al., 2012; Murashov et al., 2018). Although CFZ showed its strong inhibitory activity against $\mathrm{RABV}$ in vitro, the higher concentration in subcutaneous fat tissue and extremely low content in cerebrospinal fluid may account for the lower antiRABV activity in vivo. Obviously, for the neurotropic virus such as $\mathrm{RABV}$, increasing the concentration of antivirals in central nervous system (CNS) is the key to improve the antiviral activity (Quiñones-Torrelo et al., 2002). Therefore, CFZS was designed as the ideal alternative of CFZ to improve anti-RABV activity in vivo with a higher permeability to the blood-brain barrier and a less accumulation in adipose tissue. Pharmacokinetic studies need to be done to determine if CFZS crosses the blood-brain barrier and accumulates to a lesser extent in adipose tissues than CFZ.

To simulate the natural infection mode of human being bitten by dogs infected with RABV, mice were challenged by IM injection. Compared with intracerebral injection, challenging by IM allowed longer incubation period and a relatively slow symptom appearance, which is conducive to investigate the preventive effect of the treatment after exposure. Morever, Further studies on the anti-RABV effects of CFZ and CFZS could be perfomed on large laboratory animals such as Beagles even non-human primates.

In this study, CFZ and CFZS increased survival when administration was begun 1 day or 2 days after infection, but there was no statistical significance between treatment groups and vehicle control group. We found that efficacies of CFZ, CFZS, and T-705 against RABV showed different tendencies when administration was delayed. T-705 was effective when administered beginning $1 \mathrm{~h}$ or 1 day after inoculation. However, the CFZ and CFZS treated group exhibited better survival when administration commenced 1 day or 2 days after inoculation. This difference suggested that CFZ and T705 may act on different stages of RABV infection and/or have different mechanisms of antiviral activity. Therefore, CFZ or CFZS might be used in combination with T-705 to prevent RABV infection under the conditions of unavailable PEP.

Given the high mortality and absence of approved drugs for $\mathrm{RABV}$ infections, experimental therapies with limited proof-of concept data for efficacy are worthy of application in infected patients under expanded use authorizations. Ketamine reportedly inhibits RABV replication in cell cultures at high concentrations
(1-2 mM) by inhibiting genomic transcription (Lockhart et al., 1992). Compared with ketamine, CFZ can inhibit RABV at a lesser concentrations $(2-33 \mu \mathrm{M})$. However, the negative results in vivo highlight concerns about extrapolating from in vitro to in vivo and the question of how $\mathrm{EC}_{50}$ values from in vitro assays correlate to protective levels in animal models. Factors such as the type of formulation (research-grade or pharmaceutical), drug-drug interactions, or even interspecies differences in gastrointestinal adsorption may have effects (Pelkonen et al., 2001). Importantly, for the treatment of neurological diseases, many obstacles must be overcome to effectively deliver therapeutic agents to the central nervous system, such as uptake of the drug by the blood-brain barrier and blood-spinal cord barrier.

\section{CONCLUSION}

In summary, we have demonstrated for the first time that CFZ and CFZS exhibit potential activity against RABV infection worthy for next investigation. This study lays the foundation for identifying more effective RABV inhibitors, and discovering more optimal analogs for the treatment of RABV infection by modifying the CFZ structures.

\section{DATA AVAILABILITY STATEMENT}

The original contributions presented in the study are included in the article/Supplementary Material, further inquiries can be directed to the corresponding authors.

\section{ETHICS STATEMENT}

The animal study was reviewed and approved by the Institutional Animal Care and Use Committee, National Institutes for Food and Drug Control.

\section{AUTHOR CONTRIBUTIONS}

JW, SC, SL, QL. DS, YL and YW contributed the central idea, analysed most of the data, and wrote the initial draft of the paper. The remaining authors contributed to refining the ideas, carrying out additional analyses and finalizing this paper.

\section{FUNDING}

This work was supported by the National Natural Science Foundation of China (Grant No. 8187131465).

\section{ACKNOWLEDGMENTS}

We are grateful to Zhiguo Liu and Huili Huang from the Institute for Laboratory Animal Resources, NIFDC, for 
helping in animal experiments. We also thank Zongge Zhao and Lihua Xie from the Institute for Reference Standards and

\section{REFERENCES}

Anindita, P. D., Sasaki, M., Okada, K., Ito, N., Sugiyama, M., Saito-Tarashima, N., et al. (2018). Ribavirin-related compounds exert in vitro inhibitory effects toward rabies virus. Antiviral Res. 154, 1-9. doi:10.1016/j.antiviral.2018.03.011

Arias, A., Thorne, L., and Goodfellow, I. (2014). Favipiravir elicits antiviral mutagenesis during virus replication in vivo. Elife 3, e03679. doi:10.7554/ eLife.03679

Banyard, A. C., Mansfield, K. L., Wu, G., Selden, D., Thorne, L., Birch, C., et al. (2019). Re-evaluating the effect of Favipiravir treatment on rabies virus infection. Vaccine 37 (33), 4686-4693. doi:10.1016/j.vaccine.2017.10.109

Basu, A., Mills, D. M., and Bowlin, T. L. (2010). High-throughput screening of viral entry inhibitors using pseudotyped virus. Curr. Protoc. Pharmacol. Chapter 13, Unit 13B.3. doi:10.1002/0471141755.ph13b03s51

Browne, S. G., Harman, D. J., Waudby, H., and McDougall, A. C. (1981). Clofazimine (Lamprene, B663) in the treatment of lepromatous leprosy in the United Kingdom. A 12 year review of 31 cases, 1966-1978. Int. J. Lepr. Other Mycobact Dis. 49 (2), 167-176.

Cholo, M. C., Steel, H. C., Fourie, P. B., Germishuizen, W. A., and Anderson, R. (2012). Clofazimine: current status and future prospects. J. Antimicrob. Chemother. 67 (2), 290-298. doi:10.1093/jac/dkr444

Davis, B. M., Rall, G. F., and Schnell, M. J. (2015). Everything you always wanted to know about rabies virus (but were afraid to ask). Annu. Rev. Virol. 2 (1), 451-471. doi:10.1146/annurev-virology-100114-055157

Dharmalingam, B., and Jothi, L. (2015). RDIS: the rabies disease information system. Bioinformation 11 (11), 506-508. doi:10.6026/97320630011506

Faouzi, M., Starkus, J., and Penner, R. (2015). State-dependent blocking mechanism of Kv 1.3 channels by the antimycobacterial drug clofazimine. Br. J. Pharmacol. 172 (21), 5161-5173. doi:10.1111/bph.13283

Fooks, A. R., Banyard, A. C., Horton, D. L., Johnson, N., McElhinney, L. M., and Jackson, A. C. (2014). Current status of rabies and prospects for elimination. Lancet 384 (9951), 1389-1399. doi:10.1016/S0140-6736(13)62707-5

Fooks, A. R., Cliquet, F., Finke, S., Freuling, C., Hemachudha, T., Mani, R. S., et al. (2017). Rabies. Nat. Rev. Dis. Primers 3, 17091. doi:10.1038/nrdp.2017.91

Jackson, A. C. (2013). Current and future approaches to the therapy of human rabies. Antiviral Res. 99 (1), 61-67. doi:10.1016/j.antiviral.2013.01.003

Leanza, L., O’Reilly, P., Doyle, A., Venturini, E., Zoratti, M., Szegezdi, E., et al. (2014). Correlation between potassium channel expression and sensitivity to drug-induced cell death in tumor cell lines. Curr. Pharm. Des. 20 (2), 189-200. doi:10.2174/13816128113199990032

Liu, B., Liu, K., Lu, Y., Zhang, D., Yang, T., Li, X., et al. (2012). Systematic evaluation of structure-activity relationships of the riminophenazine class and discovery of a C2 pyridylamino series for the treatment of multidrug-resistant tuberculosis. Molecules 17 (4), 4545-4559. doi:10.3390/molecules 17044545

Lockhart, B. P., Tordo, N., and Tsiang, H. (1992). Inhibition of rabies virus transcription in rat cortical neurons with the dissociative anesthetic ketamine. Antimicrob. Agents Chemother. 36 (8), 1750-1755. doi:10.1128/aac.36.8.1750

Lu, Y., Zheng, M., Wang, B., Fu, L., Zhao, W., Li, P., et al. (2011). Clofazimine analogs with efficacy against experimental tuberculosis and reduced potential for accumulation. Antimicrob. Agents Chemother. 55 (11), 5185-5193. doi:10. 1128/AAC.00699-11

Marosi, A., Dufkova, L., Forró, B., Felde, O., Erdélyi, K., Širmarová, J., et al. (2019). Combination therapy of rabies-infected mice with inhibitors of proinflammatory host response, antiviral compounds and human rabies immunoglobulin. Vaccine 37 (33), 4724-4735. doi:10.1016/j.vaccine.2018. 05.066

Murashov, M. D., LaLone, V., Rzeczycki, P. M., Keswani, R. K., Yoon, G. S., Sud, S., et al. (2018). The physicochemical basis of clofazimine-induced skin pigmentation. J. Invest. Dermatol. 138 (3), 697-703. doi:10.1016/j.jid.2017. 09.031
Standardization, NIFDC, for providing the small molecular compounds.

Nie, J., Wu, X., Ma, J., Cao, S., Huang, W., Liu, Q., et al. (2017). Development of in vitro and in vivo rabies virus neutralization assays based on a high-titer pseudovirus system. Sci. Rep. 7, 42769. doi:10.1038/srep42769

World Health Organization (2013). WHO expert consultation on rabies. Second report. World Health Organ. Tech. Rep. Ser. (982), 1-139.

Pelkonen, O., Boobis, A. R., and Gundert-Remy, U. (2001). In vitro prediction of gastrointestinal absorption and bioavailability: an experts' meeting report. Eur. J. Clin. Pharmacol. 57 (9), 621-629. doi:10.1007/s002280100369

Brazilian Rabies Survivor (2008). Ministerio da Saude, Secrearia de Vigilancia em Saude, Brazil. Rabies, human survival, bat-Brazil: (Pernambuco). Available at: http://www.promedmail.org (Accessed January 28, 2014).

Quiñones-Torrelo, C., Martin-Biosca, Y., Martínez-Pla, J. J., Sagrado, S., Villanueva-Camañas, R. M., and Medina-Hernández, M. J. (2002). QRAR models for central nervous system drugs using biopartitioning micellar chromatography. Mini Rev. Med. Chem. 2 (2), 145-161. doi:10.2174/ 1389557024605519

Smith, J. S., Yager, P. A., and Baer, G. M. (1973). A rapid reproducible test for determining rabies neutralizing antibody. Bull. World Health Organ. 48 (5), 535-541.

Ulferts, R., de Boer, S. M., van der Linden, L., Bauer, L., Lyoo, H. R., Maté, M. J., et al. (2016). Screening of a library of FDA-approved drugs identifies several enterovirus replication inhibitors that target viral protein 2C. Antimicrob. Agents Chemother. 60 (5), 2627-2638. doi:10.1128/AAC.02182-15

Virojanapirom, P., Lumlertdacha, B., Wipattanakitchareon, A., and Hemachudha, T. (2016). T-705 as a potential therapeutic agent for rabies. J. Infect. Dis. 214 (3), 502-503. doi:10.1093/infdis/jiw174

Wang, S., Liu, Y., Guo, J., Wang, P., Zhang, L., Xiao, G., et al. (2017). Screening of FDA-approved drugs for inhibitors of Japanese encephalitis virus infection. J. Virol. 91 (21). doi:10.1128/JVI.01055-17

Weli, S. C., Scott, C. A., Ward, C. A., and Jackson, A. C. (2006). Rabies virus infection of primary neuronal cultures and adult mice: failure to demonstrate evidence of excitotoxicity. J. Virol. 80 (20), 10270-10273. doi:10.1128/JVI. 01272-06

Wiedeman, J., Plant, J., Glaser, C., Messenger, S., Wadford, D., Sheriff, H., et al. (2012). Recovery of a patient from clinical rabies--California, 2011. MMWR Morb Mortal Wkly Rep. 61 (4), 61-65.

Willoughby, R. E., Jr., Tieves, K. S., Hoffman, G. M., Ghanayem, N. S., AmlieLefond, C. M., Schwabe, M. J., et al. (2005). Survival after treatment of rabies with induction of coma. N. Engl. J. Med. 352 (24), 2508-2514. doi:10.1056/ NEJMoa050382

Wu, J., Liu, Q., Xie, H., Chen, R., Huang, W., Liang, C., et al. (2019). Screening and evaluation of potential inhibitors against vaccinia virus from 767 approved drugs. J. Med. Virol. 91 (11), 2016-2024. doi:10.1002/jmv.25544

Yamada, K., Noguchi, K., Kimitsuki, K., Kaimori, R., Saito, N., Komeno, T., et al. (2019). Reevaluation of the efficacy of favipiravir against rabies virus using in vivo imaging analysis. Antiviral Res. 172, 104641. doi:10.1016/j.antiviral.2019.104641

Yamada, K., Noguchi, K., Komeno, T., Furuta, Y., and Nishizono, A. (2016). Efficacy of favipiravir (T-705) in rabies postexposure prophylaxis. J. Infect. Dis. 213 (8), 1253-1261. doi:10.1093/infdis/jiv586

Conflict of Interest: The authors declare that the research was conducted in the absence of any commercial or financial relationships that could be construed as a potential conflict of interest.

Copyright (C) $2021 \mathrm{Wu}$, Cao, Lei, Liu, Li, Yu, Xie, Li, Zhao, Chen, Huang, Xiao, Yu, Song, Li and Wang. This is an open-access article distributed under the terms of the Creative Commons Attribution License (CC BY). The use, distribution or reproduction in other forums is permitted, provided the original author(s) and the copyright owner(s) are credited and that the original publication in this journal is cited, in accordance with accepted academic practice. No use, distribution or reproduction is permitted which does not comply with these terms. 